\title{
SPATIAL RELATIONSHIP BETWEEN PLACEMENT OF SHRINES AND RISK OF FLOODING IN LOW-LYING AREAS AT THE EASTERN TOKYO METROPOLITAN REGION
}

\author{
HIROSHI GOTOH \\ Department of Town Planning and Design, College of Science and Technology, Nihon University, Japan
}

\begin{abstract}
Since ancient times, in Japan, shrines and temples have been a gathering place for local people to say prayers for their well-being. Also, shrines are commonly used by communities as evacuation centers in the event of a disaster at the present time. However, if the location of the shrine in the evacuation area is vulnerable to disasters, then the ramifications in terms of safety could be very serious. In this study, the author examined the spatial distribution of shrines in low-lying areas of eastern Tokyo. Recently, it was reported that shrines damaged by the tsunami that followed the Great East Japan Earthquake are related to the kind of main deities. In particular, since extensive ground subsidence has occurred in the low lying areas of eastern Tokyo, the author investigated the ground height before ground subsidence occurred based on land subsidence data, and considered the relationship between the ground height and the enshrined main deities at shrines taking into account with the danger of flood damage. The area where the shrine is located is thought to have existed as a town since ancient times. As a result, the area is generally considered to be less affected by floods. The information obtained from this survey will confirm the truth of this tradition, and will be useful for the management of urban planning from the viewpoint of disaster prevention.
\end{abstract}

Keywords: shrine, deities, low-lying areas of Tokyo, evacuation areas, subsidence, flood hazard.

\section{INTRODUCTION}

In the last decade, Japan has experienced several largescale natural disasters: the tsunami caused by the Great East Japan Earthquake that occurred on 11 March 2011, flooding of the Kinugawa River caused by the heavy rains in the Kanto and Tohoku regions that occurred on 11-12 September 2015, and flooding that occurred over a wide area of western Japan due to heavy rains on 3-8 July 2018 [1]. Of these events, the tsunami caused by the Great East Japan Earthquake caused the most extensive damage to shrines in the region. These shines, which are traditionally regarded as safe spaces by local communities, were the sites of extensive loss of life because people believed that they would be safe there [2]. As an example of recent river flooding, the Nagano Hachiman Shrine was damaged by the heavy rains caused by Typhoon No. 19 in 2020 [3], and the Aso Shrine, which is a national treasure, was damaged by the heavy rains in July 2021 [4].

Regarding the flood damage caused by the tsunami after the Great East Japan Earthquake, Uda et al. reported that there were many shrines near the periphery of the flooded area [2]. They therefore proposed that, historically, residents of areas that are susceptible to flooding may have built shrines in areas that were considered to be safe from tsunamis. Similarly, Hattori and Nii examined the spatial relationships among shrines, villages, and rivers in flood-prone areas of the Kurobe River alluvial fan [5]. Their findings showed that shrines are often located along the valley ridge line, which is the microtopography of the alluvial fan flood channel. Thus, they considered that the shrines played an important role in protecting local inhabitants against flood damage. Furthermore, Takada et al. [6] categorized the occurrence or absence of inundation damage to shrines caused by the Great East Japan 
Earthquake tsunami by focusing on the main deity, and showed that there were differences in the extent of damage depending on the deity. Specifically, they found that damage to the Shinto shrines - an ancient religion practiced in Japan in which numerous deities have specific roles - differed depending upon the deity being glorified. Further, they showed that the extent of flood damage caused by the tsunami to shrines dedicated to the god of hydraulic control, "Susanoo" (e.g., the Kumano and the Hachiman shrines), was limited. The results of Takada's survey has potential that serve as a reference material for future infrastructure management, urban planning, and urban design in Japan. However, the application of this hypothesis, which Shrines dedicated to Susanoo are resistant to floods to flood control in other areas, is unknown. In order to test this hypothesis, it is necessary to investigate other areas.

In this study, the author targeted four low-lying wards (Taito, Sumida, Arakawa, and Koto wards) in the eastern part of Tokyo that are vulnerable to river floods and storm surges. The relationship between the spatial characteristics of the shrines and the main deity were analyzed, by referring to the study by Takada et al. [6] For comparison, the author conducted a survey on the location of churches, which serve the same purpose as shrines abroad, in lowlying areas near Amsterdam and in north Holland.

\section{METHODOLOGY}

The areas investigated were Arakawa Ward, Sumida Ward, Taito Ward, and Koto Ward, which are all low-lying areas (zero-meter zone, i.e., located at under the mean sea level) in the eastern part of Tokyo. First, the author investigated the history of flood damage during the Edo period, when the lowland areas of eastern Tokyo began to develop, by surveying the literature [7]. A general residential map was used to locate all of the shrines in the four wards [8]. Each site was then visited on foot to confirm the identity of the main deity to which the shrine was dedicated. In the absence of any information at the site of the shrine, the homepages of shrines were consulted [9], [10]. Next, in order to determine the altitude of each shrine, information on the current ground level was obtained from the website of the Geospatial Information Authority of Japan [11]. The predicted inundation depth at each shrine was then obtained from a hazard map issued by the local government, and compared with the ground level [12]-[15]. These estimates were necessary because considerable ground subsidence has occurred in the study area since the shrines were built, primarily due to excessive pumping of groundwater from the early Showa period to around 1970 [16]. In order to accurately determine the extent of land subsidence at the location of each shrine, the author obtained annual elevation data from the Tokyo Metropolitan Government Bureau of Construction. Since the spatial extent of the benchmarks measured in Tokyo has increased in number over time, some benchmarks were measured after severe land subsidence occurred. Therefore, in order to estimate the ground level as close to the Edo period as possible, the author selected and examined data for old benchmarks that were measured before the early Showa period (around 1935). The cumulative subsidence was then calculated and added to the current ground level by referring to the amount of ground subsidence for each year obtained from the old benchmark data nearest to each shrine. In this way, the ground level before land subsidence occurred was estimated, and the geographic locations of shrines dedicated to deities that offer protection from flood damage were examined. Some shrines in Japan have been relocated in the past, but it was sometimes difficult to investigate the relocation history; in such cases the author assumed that the shrine had been located at the current location for a long time. The author also examined Christian churches in this study because they fulfill a role similar to Shinto shrines in Japan, i.e., they serve as places of worship and protection. For reference, the author selected areas in north Holland and the city 
of Amsterdam in The Netherlands, as most of these areas are also located at or below sea level. The existence of churches was confirmed on Google Maps [17], and data on the ground level was determined using an electronic map published by the Geospatial Information Authority of Japan [11]. In this way, the ground level at each church location was measured.

\section{RESULTS ON LITERATURE REVIEW ON SPATIAL LOCATIN OF SHRINE}

\subsection{History of flood damage in Edo area during Edo period}

Fig. 1 shows a regional map of Edo, the old part of Tokyo. In this map, the locations of the three major floods in Edo are shown.

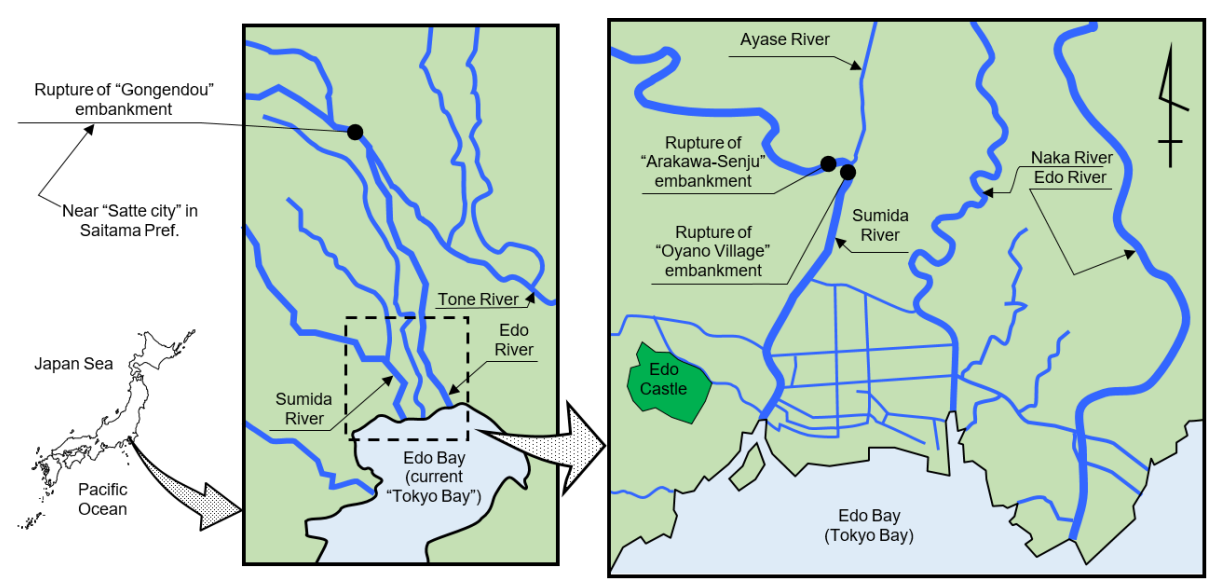

Figure 1: State of Edo (Tokyo) during the Edo era with insets showing rivers that experienced flooding and locations of three ruptured river embankments.

There were numerous floods in Edo (Fig. 1) during the Edo period (1603-1868), when many shrines are thought to have been built. It can be read from the literature that numerous floods occurred during this period and caused considerable damage [7]. It is likely that there were many more small and medium-sized flood disasters not mentioned in the literature [7]. Since the urban areas in the low-lying areas in the eastern part of Tokyo are built on a very large alluvial, these areas were greatly affected by both river floods and storm surges. According to the history of Katsushika Ward [18], the three major floods that occurred in Edo (Table 1) were caused by the collapse of the Kotanomura embankment in 1742 (Kanpo 2), the collapse of the Gongendo embankment in 1786 (Tenmei 6), and the collapse of the Arakawa Senju embankment in 1846 (Koka 3). Fig. 1 shows the locations of each breach. As can be seen, the levees broke near the center of Edo. Other literature sources corroborate the information shown in Table 1. According to the history of Katsushika Ward, in 1680 (Enpo 8), 1742 (Kanpo 2, one of the three major floods in Edo), 1791 (Kansei 3), 1823 (Bunsei 6) and 1856 (Ansei 3), the Katsushika area of Tokugawa Shogunate (currently, Chiba Prefecture, Saitama Prefecture, and northeastern Tokyo [19]) experienced severe damage due to high tides along the coast. It is therefore presumed that the residents in this area would have relied on deities to protect them from repeated water-related disasters and that this would be reflected in the spatial arrangement of shrines dedicated to deities that protected people from water-related disasters. 
Table 1: Relationship between kind of deity and estimated maximum inundation depth.

\begin{tabular}{|l|c|c|c|c|c|c|}
\hline \multirow{2}{*}{ Blessing } & \multicolumn{6}{|c|}{ Estimated inundation depth } \\
\cline { 2 - 8 } & $0 \mathrm{~m}$ & $\leq 0.5 \mathrm{~m}$ & $\leq 1 \mathrm{~m}$ & $\leq 3 \mathrm{~m}$ & $\leq 5 \mathrm{~m}$ & $>5 \mathrm{~m}$ \\
\hline $\begin{array}{l}\text { God of everything (main deity in } \\
\text { Japanese mythology) }\end{array}$ & & & & 4 & 4 & \\
\hline Good luck & & 1 & 1 & 3 & 1 & \\
\hline Peace on Earth & 1 & 1 & & 17 & 11 & \\
\hline Good harvests (Inari system) & & 1 & 2 & 23 & 18 & \\
\hline Victory in war & & & & 8 & 5 & 1 \\
\hline Academic achievement & & & 2 & & \\
\hline
\end{tabular}

3.2 Relationship between ground level before ground subsidence and deities

Using a residential map, a total of 113 shrines were extracted in the survey area. The characteristics of these 113 shrines are described below. The author visited all 113 shrines and was able to identify the deities of all but two shines: Inari Daimeijin (Eitai, Koto-ku) and Fushimi Inari Shrine (Eitai, Koto Ward). There is one shrine (Fuji Inari Shrine (Eda-gawa, Koto Ward)) that had been built on reclaimed land around 1920 [20]. There are six shrines on the Musashino terrace: Koryō Inari Shrine (Nishi Nippori, Taito Ward), Suwa Shrine (Nishi Nippori, Arakawa Ward), Hanazono Inari Shrine (Ueno Park, Taito Ward), Nanakura Inari (Ikenohata, Taito Ward), Gojo Tenjin Shrine (Ueno Park, Taito Ward), Ueno Toshogu Shrine (Ueno Park, Taito Ward). There are 104 shrines located on plains that were built on sandbars including reclaimed land, back marshes, and land on natural levees [21]. In this study, these 104 shrines located on the alluvial plain are examined. Referring to Takada et al. [6], the deities were classified as follows: (1) the main deity of Japanese mythology (the Shinto religion) called as Amaterasu Okami; (2) the deity that brings good luck to local residents; (3) the deity of peace on Earth (creator of the Earth and mountains, control of oceans and rivers, protection from fire and wind damage); (4) the deity of the Inari system (ensures good harvests, acquisition of wealth, business prosperity, good health of children); (5) the deity of victory in war (the god of warriors such as the Shogun and Yamato Takeru); and (6) the deity of academic learning. Table 1 shows the relationship between the main deity and the maximum inundation depth at the shrine estimated based on the inundation hazard map issued by the local government. It was difficult to find a statistically significant between the main god and the predicted inundation depth estimated using the current level of the ground. So, it was found that most shrines would be flooded in the event of a flood. As mentioned above, shrines are often not well suited for use as evacuation shelters during floods. In addition, it was difficult to determine the relationship on the spatial arrangement between the danger of flooding and the kind of main deity based on the current ground level. Consequently, the author decided to proceed again with the study taking into consideration the effects of severe land subsidence that occurred mainly in the 1970s from 1925 (early Showa period).

Specifically, the author estimated the ground level in the Edo era with reference to the fluctuation history of the nearest benchmark of each shrine measured from the beginning of the Meiji era (1868-1912), the Taisho era (1912-1926), and the Showa era (1929-1989). The author then reproduced the condition of the ground level before subsidence and tried to reexamine it. Fig. 2 shows the changes in land subsidence from 1929 (Showa 4) to 2018. As can be seen, the maximum subsidence in the study area since 1929 is at least $3 \mathrm{~m}$. Indeed, based on benchmark levels measured since the Meiji era, there are some points where the 
ground level has changed by $4 \mathrm{~m}$ or more. Fig. 3 shows the relationships among the current ground level, the ground level at around the Edo period, and the main enshrined deities. The results show that during the Edo period, in this area, it was not the area that was not at under the sea level like it is today. Inari shrines and shrines for praying for happiness should be familiar to residents. Therefore, as shown in Fig. 3, it can be seen that the shrines are arranged in a wide range of ground heights so as to be close to the place where the inhabitants live in the Edo period. In addition, it was difficult to determine whether a shrine was dedicated to academic achievement because the number of samples was small, but such shrines were considered to be the same as the Inari system shrines because they are located close to residential areas. Furthermore, as reported by Takada et al. [6], shrines dedicated to Amaterasu were considered to be located in areas of high ground because Amaterasu has been the supreme deity related Japanese mythology and revered by Japanese people, and can therefore be regarded as having similar characteristics to Inari system shrines. On the other hand, shrines dedicated to peace on Earth and victory in war, as shown in Fig. 3, were built on ground that was slightly higher than the others(Amaterasu, Good luck, Good harvest, and Academic achievement). The locations of these(Peace on Earth and Victory in war) shrines are located seems to have been slightly higher than the surrounding area. The difference in ground height could not be determined clearly in the previous discussion, a one-way analysis of variance (ANOVA) was performed to confirm whether there is a significant difference in the mean value of ground height. Table 2 shows the calculation results. The results indicate that the hypothesis that the ground level of the shrine does not depend on the type of deity enshrined could not be rejected at a significance level of $5 \%$. Therefore, there was no stochastic difference in the mean value of ground height. In other words, as concluded by Takada et al., it was not possible to demonstrate that there is a difference in the environment in which it is difficult to encounter flood damage depending on the kind of deity.

\subsection{Spatial arrangement of churches in lowlands of northern Holland}

The author extracted 25 churches in Amsterdam and 100 churches in the low-lying areas of north Holland along the transect indicated by A-B shown in Fig. 4.

Then, the author investigated the ground level at the location of each church and arranged the percentage for each ground level. Fig. 5 shows the frequency distribution of churches and their heights above sea level. In Europe, churches are typically located in center of towns. Fig. 6 shows the $\mathrm{C}-\mathrm{D}$ transect through Amsterdam shown in Fig. 4. This is a cross section

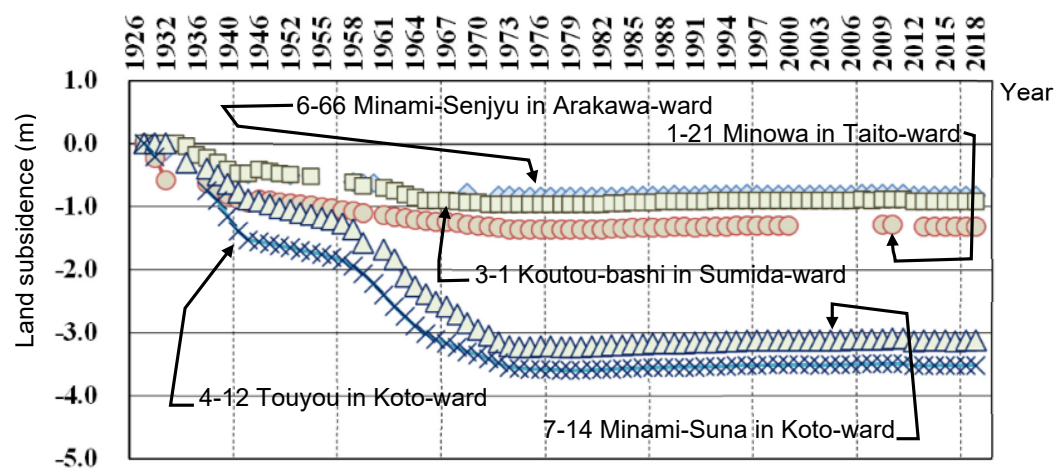

Figure 2: Land surface subsidence at several sites in the survey area over time. 


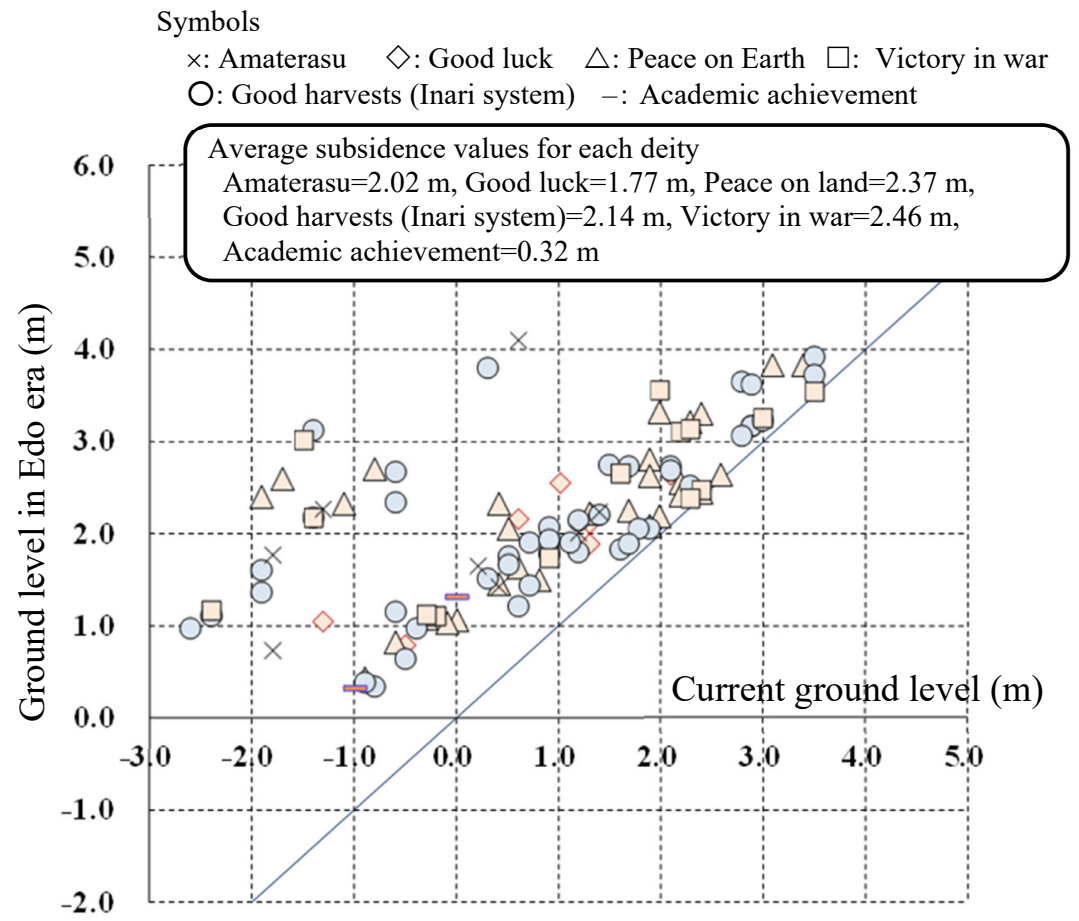

Figure 3: Relationship between deities and ground level.

Table 2: Results of one-way ANOVA.

\begin{tabular}{|l|c|c|c|c|c|c|}
\hline \multicolumn{7}{|c|}{ Overview } \\
\hline Group & $\begin{array}{c}\text { Number of } \\
\text { shrines }\end{array}$ & Total & Average & \multicolumn{2}{|c|}{ Variance } \\
\hline Amaterasu & 8 & 16.161 & 2.020 & \multicolumn{2}{|c|}{0.950} \\
\hline Good luck & 6 & 10.639 & 1.773 & 0.506 \\
\hline $\begin{array}{l}\text { Peace on } \\
\text { Earth }\end{array}$ & 30 & 71.135 & 2.371 & \multicolumn{2}{|c|}{1.192} \\
\hline Good harvest & 44 & 94.464 & 2.147 & \multicolumn{2}{|c|}{0.850} \\
\hline Victory in war & 14 & 34.442 & 2.460 & \multicolumn{2}{|c|}{0.5790} \\
\hline $\begin{array}{l}\text { Academic } \\
\text { achievement }\end{array}$ & 2 & 1.643 & 0.822 & & Boundary \\
\hline & \multicolumn{7}{|c|}{ Table of analysis of variance } \\
\hline $\begin{array}{l}\text { Fluctuation } \\
\text { type }\end{array}$ & Fluctuation & $\begin{array}{c}\text { Degrees of } \\
\text { freedom }\end{array}$ & Variance & $\begin{array}{c}\text { Observed } \\
\text { variance } \\
\text { ratio }\end{array}$ & P value \\
\hline $\begin{array}{l}\text { Between } \\
\text { groups }\end{array}$ & 7.101 & 5 & 1.4202 & 1.531 & 0.187 & 2.31 \\
\hline Within groups & 90.923 & 98 & 0.928 & & & \\
\hline Total & 98.024 & 103 & & & & \\
\hline
\end{tabular}




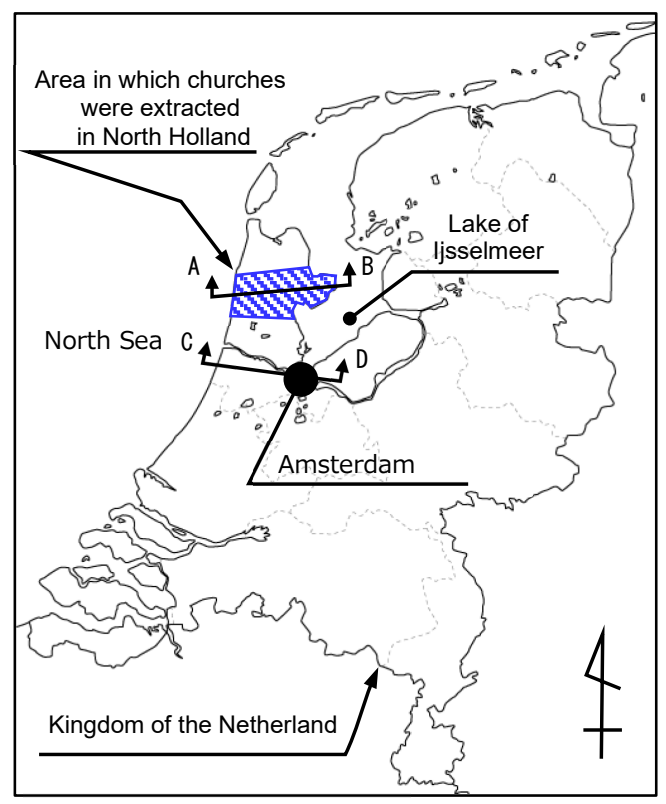

Figure 4: Area in which churches were extracted in The Netherlands.

obtained from the Geospatial Information Authority of Japan [11], and it can be seen that the city of Amsterdam was originally built on a hill. Most of the churches constructed in region are therefore built on high ground (Fig. 5). Fig. 7 shows a cross-sectional view of the A-B transect in north Holland shown in Fig. 4. Much of the land between the land protected by the coastal embankments at the North Sea and at Lake Ijsselmeer is at sea level. According to $1 \mathrm{~m}$ ground level data for The Netherlands obtained from the Geospatial Information Authority of Japan, no further details of the unevenness of the ground is known. However, as shown in Fig. 5, the ground level at the locations where some churches were built was below sea level, but in most cases, the ground level is above sea level. Therefore, although this area is lowland, it is considered that churches, which became the centers of towns, were established in areas that were slightly elevated. These churches then attracted residents, and the town developed and expanded. Thus, the density and placement of churches in elevated areas may have been to avoid damage due to inundation and, particularly, flood damage.

\section{CONSIDERATIONS RELATED TO THE USE OF SHRINES AS EVACUATION SITES IN THE EVENT OF DISASTERS IN JAPAN}

In the four wards targeted in the eastern lowlands of Tokyo, like the shrines on the Pacific coast of the Tohoku region, it was not found that shrines dedicated to specific deities were spatially arranged to avoid disasters. However, shrines are considered to function as centers of communities, where many people gather at local festivals, and as places to worship deities on a daily basis. The shrine grounds, although generally large in size, are safe from earthquakes as there are no tall buildings. They are also famous landmarks in the area, there is a possibility so each family member decide to use them as a meeting place in case of disaster. When the author surveyed the evacuation facilities for disaster countermeasures in 


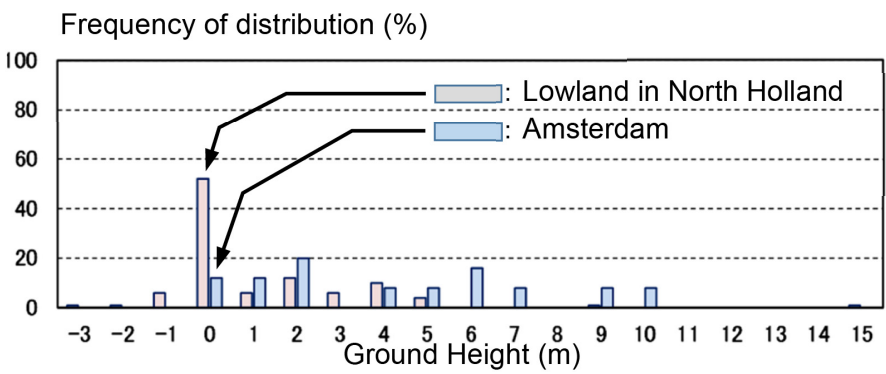

Figure 5: Distribution of ground height at church locations in different regions of The Netherlands.

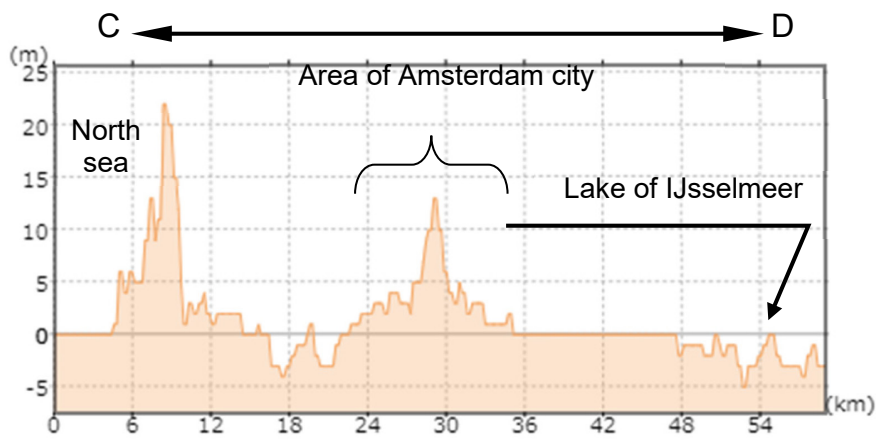

Figure 6: C-D transect through Amsterdam and surrounding area. (Source: Modified from [11].)

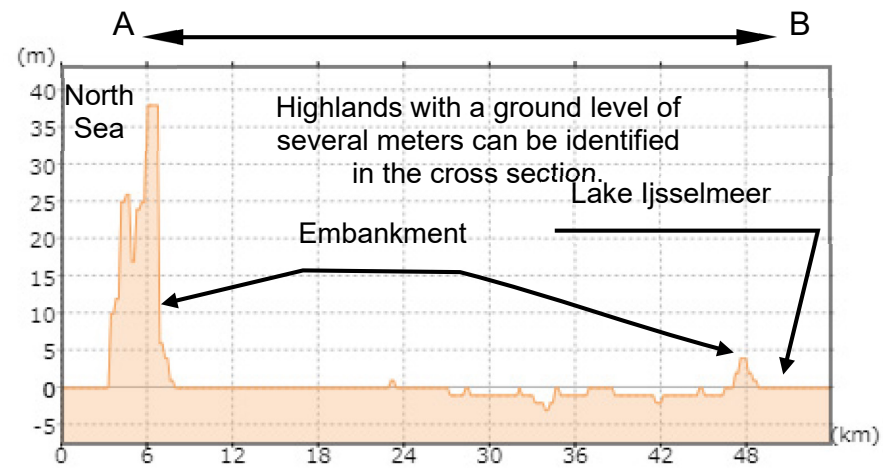

Figure 7: A-B transect in north Holland. (Source: Modified from [11].)

the four wards, most were public facilities such as schools; shrines were typically not designated as evacuation centers. Indeed, the survey showed that this is the case in many of the other wards in Tokyo. However, although the number was not large, there were some 
cases where shrines and temples were designated as temporary meeting places in the event of disasters caused by fire or earthquakes. It is considered that some residents cannot distinguish between the evacuation sites on disasters caused by fire/earthquakes and those due to flooding. Therefore, depending on the type of disaster(earth quake, fire and flooding), it is considered necessary to inform local residents of the locations of evacuation facilities and temporary meeting places.

\section{CONCLUSION}

The results of this study are summarized briefly. In the eastern lowland of Tokyo, there was no difference in the arrangement of shrines according to the type of deity, based on the present ground level. However, when cumulative ground subsidence was taken into account, the average ground height of shrines dedicated to deities responsible for peace on earth and victory in war was slightly higher than that of other shrines. However, a one-way analysis of variance (ANOVA) showed that there was no significant difference in ground height between the shrines.

Japanese people perceive areas with shrines as ancient towns, which would be safe against floods. In urbanized Tokyo, shrines have existed for a long time, but they are not always located on higher ground due to land alteration. Therefore, it was found that the areas where shrines are located may also be affected by floods. Therefore, the author believes that, from the perspective of disaster prevention in urban planning, shrines in Tokyo are not suitable as evacuation sites in the event of floods, and therefore, careful publicity should be promoted to residents.

In some areas of Japan, shrines are used as shelters. Therefore, I will conduct further research on the relationship between floods and the experience of damage at shrines and the actual situation of evacuation sites during floods.

As an example of the layout of religious sites outside Japan, The author have investigated the lowlands of The Netherlands and found that churches are located on slightly higher ground. In the future, the author would also like to focus on the lowlands of The Netherlands and consider classifying the layout of churches according to denomination, such as whether they are Catholic or Protestant.

\section{ACKNOWLEDGEMENT}

The author would like to express their gratitude to the Technical Support and Human Resource Development Center of the Tokyo Metropolitan Government Bureau of Construction who provided the benchmark data used in this study.

\section{REFERENCES}

[1] Japan Meteorological Agency, Meteorological cases that caused disasters. https://www.jma.go.jp/jma/index.html. Accessed on: 1 Mar. 2019.

[2] Uda, T. et al., Damage due to the 2011 Great Tsunami and shrines that escaped from being damaged. Journal of Japan Society of Civil Engineers B3 (Ocean Engineering), 68(2), pp. 43-48, 2012. (In Japanese.)

[3] Mainichi Newspaper, Inauguration ceremony of a new shrine in Nagano City, An area affected by Typhoon No. 19. https://mainichi.jp/articles/20201002/k00/00m/040/ 038000c. Accessed on: 18 Mar. 2021.

[4] Yomiuri Newspaper, Heavy rains cause flooding of national treasure shrine, damage to 61 cultural properties. https:/www.yomiuri.co.jp/culture/20200717-OYT1T50146/. Accessed on: 18 Mar. 2021. 
[5] Hattori. S. \& Nii, A., Basic research on the location of shrines in flood-prone areas, targeting Kurobe River fan-shaped land and Nyuzen Town, Toyama Prefecture. Proceedings of the 8th Landscape and Design Research Conference, Japan Society of Civil Engineers, pp. 241-248, 2012. (In Japanese.)

[6] Takada, T. et al., A study on the deities and spatial arrangement of shrines in tsunami disaster caused by the Tohoku Earthquake. Journal of Japan Society of Civil Engineers (Safety Problem (F6)), 68(2), pp. 167-174, 2012. (In Japanese.)

[7] Hatakeyama, N., Meteorological Disasters, Kyoritsu Shuppan Co., Ltd.

[8] Shobunsha Publications, Master of the City Tokyo 23 wards: Useful information map, 2018.

[9] Tokyo Shrine Office, Find a shrine. http://www.tokyo-jinjacho.or.jp/. Accessed on: 1 Mar. 2019.

[10] Each shrine in the five target wards: Homepage of each shrine. Accessed on: 1 Mar. 2019.

[11] Geospatial Information Authority of Japan, Electronic land WEB. http://www.gsi.go.jp/. Accessed on: 1 Mar. 2019.

[12] Arakawa Ward: Hazard map. https://www.city.arakawa.tokyo.jp/. Accessed on: 18 Mar. 2021.

[13] Sumida Ward: Hazard map. http://www.city.sumida.lg.jp/. Accessed on: 18 Mar. 2019.

[14] Taitou Ward: Hazard map, etc. https://www.city.taito.lg.jp/. Accessed on: 18 Mar. 2019.

[15] Koto Ward: Hazard map, etc. https://www.city.koto. lg.jp/. Accessed on: 1 Mar. 2019.

[16] Tokyo Metropolitan Government Bureau of Construction Koto Waterworks Office, Business summary of Koto Waterworks Office. http://www.kensetsu.metro.tokyo.jp/. Accessed on: 1 Mar. 2019.

[17] Google, Google Maps. https://www.google.com/. Accessed on: 1 Mar. 2019.

[18] Katsushika Ward: History of Katsushika Ward. http://www.city.katsushika.lg.jp/. Accessed on: 1 Mar. 2019.

[19] Asahi Newspaper, Kotobank. https://kotobank.jp/. Accessed on: 1 Mar. 2019.

[20] Tokyo Port Promotion Association, History of Tokyo harbor landfill. https://www.tokyoport.or.jp/43pdf_01.pdf. Accessed on: 1 Mar. 2019.

[21] Chuo-Kaihatsu Corporation, Ground Information Navigation. http://www.geonavi.net/georisknavi2/html/13_tokyo.html. Accessed on: 1 Mar. 2019. 